\title{
ПУБЯГЧНЕ ПРАВО
}

УДК 343.34 DOI: https://doi.org/10.31617/zt.knute.2019(106)04

ГУРжІЙ Тарас д. ю. н., професор, завідувач кафедри адміністративного, фінансового та інформаційного права Київського

E-mail: t.gurzhii@knute.edu.ua

ORCID: 0000-0002-3348-8298 національного торговельно-економічного університету

вул. Кіото, 19, м. Київ, 02156, Україна

КОВАЛЕНКО Жанна аспірант кафедри адміністративного, фінансового

E-mail: hrightsfor@gmail.com та інформаційного права Київського національного

ORCID: 0000-0002-5028-2400 торговельно-економічного університету

вул. Кіото, 19, м. Київ, 02156, Україна

\section{ГРОМАДСЬКИЙ КОНТРОЛЬ ЯК ПРАВОВА ФОРМА ВЗАЕМОДІЇ МІЖ ДЕРЖАВОЮ ТА СУСПІЛЬСТВОМ}

Проаналізовано основні підходи до визначення поняття «правова природа» та з'ясовано головні критерії ї̈ визначення. Здійснено розмежування громадського контролю та суміжних понять. Розкрито співвідношення понять «громадський контроль» та «участь в управлінні державними справами». Обтрунтовано авторське бачення поняття «правова природа громадського контролю». Встановлено, що варто розуміти під громадським контролем.

Ключові слова: правова природа, держава, суспільство, громадський контроль, участь в управлінні державними справами.

Гуржий Т., Коваленко Ж. Общественный контроль как правовая форма взаимодействия между государством и обществом. Проанализированы основные подходы к определению понятия «правовая природа» и выяснены главные критерии ее определения. Осуществлено размежевание общественного контроля и смежных понятий. Раскрыто соотношение понятий «общественный контроль» и «участие в управлении государственными делами». Обосновано авторское видение понятия «правовая природа общественного контроля». Установлено, что следует понимать под общественным контролем.

Ключевые слова: правовая природа, государство, общество, общественный контроль, участие в управлении государственными делами.

(C) Гуржій Т., Коваленко Ж., 2019 
Постановка проблеми. Швидкість та результативність реформування всіх найважливіших сфер життєдіяльності суспільства, адаптація національного законодавства до законодавства Європейського Союзу залежить від багатьох факторів, серед яких визначальне місце посідає легітимність публічної влади, що може бути забезпечена, зокрема, через налагодження зворотного зв'язку між владою та суспільством. Одна із форм такого зв' язку - це громадський контроль, який $є$ не тільки обов’ язковим елементом громадянського суспільства, а і яскравим проявом конституційної тези про те, що влада в державі походить від народу.

Функціонування громадського контролю потребує наявності відповідного правового, організаційного та інституційного базису, основою якого є акти національного законодавства. Водночас сьогодні як на рівні практики, так і на рівні теорії все ще відсутній єдиний концептуальний підхід щодо визначення правової природи цього явища. Від розв’язання цієї, на перший погляд, загальної проблеми значною мірою залежить не лише розвиток «нормальної науки», а й визначення способу правового регулювання суспільних відносин у сфері функціонування громадського контролю. У кінцевому підсумку це дозволить вдосконалити механізми взаємодії між державою та суспільством.

Аналіз останніх досліджень і публікацій. Проблематику громадського контролю досліджували фахівці різних сфер та галузей науки. Серед останніх на особливу увагу заслуговують праці представників правових наук, а саме: О. Васильченко, Л. Наливайко, О. Поклада, О. Смоляра, Р. Ткаченка, О. Хотинської-Нор [1-6]. Однак питання правової природи громадського контролю залишилися поза увагою науковців.

Метою статті $\epsilon$ визначення правової природи громадського контролю.

Результати дослідження. Поняття «правова природа» є одним iз найбільш вживаних в юридичному дискурсі. Його використовують як в історико-правових, так і в галузевих юридичних дослідженнях. Це зумовлено тим, що всі без винятку правові феномени характеризуються правовою природою.

Широке застосування поняття «правова природа» та, на перший погляд, його однозначне розуміння в жодному разі не є підставою стверджувати про точність та єдність підходів до його використання. Переважна більшість сучасних авторів не розкриває сутності цього поняття, в результаті чого проблематика правової природи так і не отримала належного теоретичного осмислення й відповідної розробки.

Водночас варто погодитися з О. Комісаровою, на думку якої, «визначення правової природи дозволяє не тільки дати правову характеристику юридичного явища, зрозуміти його місце i роль серед інших, але й виявити передумову, яка обов'язково впливає на його правову характеристику» ${ }^{1}[7$, с. 27$]$.

\footnotetext{
${ }^{1}$ Усі цитати з іншомовних джерел наведено у перекладі авторів статті.
} 
3 метою найбільш повного та точного розкриття правової природи громадського контролю, необхідно дослідити основні підходи до розуміння поняття правової природи та розкрити критерії її визначення.

Так, одним із перших, хто здійснив спробу визначити це поняття, $\epsilon$ теоретик права С. Алексєєв. На його думку, правову природу варто розглядати як юридичну і визначати їі через юридичні характеристики правового явища, які характеризують його структуру та відображають його місце і роль серед інших правових явищ відповідно до його соціальної природи [8]. Твердження є дещо суперечливим. Адже науковець розглядає правову природу як похідний феномен від природи соціальної, що апріорі передбачає соціальне наповнення норм права. Водночас дослідник прирівнює право до закону, у такий спосіб нівелюючи значення попередньої тези.

Говорячи про комплексний характер дослідження тематики правової природи, не можна не згадати російського вченого I. Матвєєва [9]. Віддаючи належне автору щодо побудови чіткої дефініції поняття «правова природа», доводиться зауважити, що ця спроба виявилася не досить вдалою, адже характеристика базової категорії «природа» через категорію сутності дуже мало сприяла розкриттю ії змісту. Річ у тім, що обидві названі категорії в науковій та довідковій літературі часто вживаються як взаємозамінні [10-12]. 3 огляду на це заміна одного терміну на інший (аналогічний) жодним чином не допомагає читачу глибше проникнути в суть аналізованого явища. Те ж саме стосується і тієї частини дефініції I. В. Матвєєва, де йдеться про «визначення правової природи явища шляхом його характеристики». Оскільки сутність будь-якого явища розкривається за допомогою його характеристики, таку ознаку неможливо визнати інформативною та хоч скільки-небудь корисною з погляду наукового розуміння.

Більш грунтовну спробу розкрити сутність правової природи здійснила О. Комісарова [7], стверджуючи, що передусім необхідно встановити сутність поняття «природа», яка розкривається через виявлення його основ. Це твердження є дещо дискусійним, адже оскільки поняття «природа» має статус категорії, а також широкі спектр застосування та діапазон розумінь, а правова природа притаманна тільки суто правовим явищам, тому розгляд його окремо від слова «правова» не дозволяє точно розкрити зміст цього поняття.

Дослідниця також визначає правову природу через поняття, як-от: першооснова, провідне, початок, суть, сутність, підстава. Подібне є помилковим, адже це не лише не вносить ясності, а й, навпаки, ще більше заплутує. Крім того, відповідно до вимог, що ставляться до термінів, останні мають вживатися лише в одному значенні - у тому, в якому їх застосовують [13].

Підсумковий висновок авторки прирівнює правову природу до правової оцінки, правової характеристики, правового режиму, функції, що взагалі позбавляє правову природу статусу окремого поняття, власної специфіки та смислового навантаження. 
Якщо ж звернутися до праць вітчизняних науковців, то вони, на жаль, не присвячували свої дослідження питанню правової природи як такої в чистому вигляді. Вважаючи ії як само собою зрозуміле явище, вони розглядали іiі лише в контексті розроблення інших наукових проблем, нерідко обмежуючися суто закріпленням іiї в назві роботи. Лише з тексту ставало зрозумілим, що мається на увазі під правовою природою.

Однак на теренах вітчизняної правової науки все ж є науковці, які досліджували проблематику правової природи (хоча й опосередковано). Серед них на особливу увагу заслуговують розробки А. Павленка [14]. Так, досліднику вдалося окреслити основні характеристики поняття правової природи, на основі яких вироблено авторське бачення дефініції цього поняття.

Безумовно, запропоноване визначення має право на життя, однак важливо 3'ясувати його обгрунтованість та якість. Для цього доцільно проаналізувати ключову істотну ознаку, яку запропонував науковець, а саме: правова природа виникає в момент пізнання права в процесі різних видів юридичної діяльності. Дійсно, правозастосовна практика містить нормативно-правову оцінку певного факту та встановлення відповідної норми права. Однак така діяльність не має на меті визначення правової природи тих чи інших правових явищ, адже іiі основне завдання - правильне застосування позитивного права. Тому запропоновані автором ознаки «розмивають» значення цього поняття, що призводить до значної втрати його наукової цінності.

Правова природа $є$ відображенням природи самого права, що $\epsilon$ предметом філософії права. Однак останнє в жодному разі не диктує необхідності методологічного виходу за межі правової науки. У цьому разі доречно виходити із загальновизнаних підходів теоретиків права до природи права.

3 цього приводу вдалою є запропонована професором С. Максимовим класифікація форм буття права, до яких варто віднести світ ідей, світ знакових форм та світ соціальних взаємодій [15]. Безсумнівно, саме в єдності цих рівнів право існує як таке. Проте зародження права в цілому (i, як наслідок, в конкретних сферах) відбувається на першому рівні - у світі ідей. Тому найбільш доречним $\epsilon$ трактування правової природи в цілому та правової природи громадського контролю зокрема в контексті ідеї, яка лежить в його основі та є соціальним наповненням правового регулювання відповідних суспільних відносин. Не можна забувати про те, що будь-яка ідея права має бути сформульована з урахуванням філософського осмислення, яке розглядає право як цінніснонормативну систему, що надалі й фундує закон.

Правова природа громадського контролю обумовлена парадигмою права, якій притаманна та чи інша ціннісно-нормативна система. Однак оскільки автори не ставили собі за мету дослідити генезис правової природи громадського контролю, то в центрі уваги цієї статті суто сучасна парадигма права i, відповідно, загальна концепція правової держави в її сучасному вимірі в цілому і в Україні зокрема. 
Так, з перших років незалежності в Україні на рівні Основного Закону закріплено головні засади правової держави, що є майже «дзеркальним» відображенням концепції правової держави, яка притаманна західній цивілізації. Але у зв'язку із відсутністю стандартів їх реалізації на практиці відповідна модель зазначала певної деформації.

Водночас для міжнародної правової системи характерний сучасний правовий концепт правової держави, сутність якого полягає в тому, що за своїм суспільно-політичним змістом теорія і практика правової держави спрямовані на утвердження принципу суверенітету народу, підпорядкування держави суспільству, захист прав і свобод людини і громадянина [16]. Останнє не лише схвалено світовою спільнотою, а й знайшло вияв в низці важливих міжнародних документів, зокрема й міжнародно-правових актів, які мають фундаментальний характер, а саме: Загальна декларація прав людини, Міжнародний пакт про громадянські та політичні права, Конвенція про захист прав людини і основоположних свобод тощо.

Ратифікація вказаних вище документів визначила курс розвитку нашої держави. В результаті в Україні утверджується концепція, за якої людина, її права і свободи розглядаються як абсолютна цінність. Останне не лише дало поштовх для створення сприятливого середовища для розвитку громадянського суспільства, а й обумовило перейняття Україною загальнолюдських цінностей, які провідні країни світу (зокрема країни СС зі сталою демократією), протягом десятиліть пропагують та неухильно дотримуються.

Проєвропейський вектор руху нашої держави обумовлює інтеграцію базових європейських цінностей, якими, на наш погляд, є: свобода та відповідальність за неї, гідність та рівність людей, правова держава, демократія, громадянське суспільство, толерантність, справедливість.

Аналіз зазначеного вище, дозволяє говорити про те, що нині у світі існує певна система соціальних цінностей. Вона є спільною для більшості країн світу, а їі елементи перебувають у тісному взаємозв'язку між собою. Водночас конституючими морально-правовими принципами й цінностями громадського контролю $є$ демократія, правова держава та громадянське суспільство. Як наслідок, для визначення правової природи досліджуваного правового явища в цілому та його ідеї зокрема необхідно розкрити взаємозв'язок демократії, правової держави та громадянського суспільства.

Розглядаючи правову державу, доречно стверджувати, що вона базується на принципі, відповідно до якого свобода однієї людини закінчується там, де починається свобода іншої. Тобто мається на увазі, що якщо хтось порушує права іншої людини, то він/вона притягується до відповідальності відповідно до норм права, що забезпечують захист прав і свобод всіх людей та громадян. Правова держава передбачає законослухняність усіх, незалежно від статусу і соціального становища. Законослухняність означає, що народ визнає чинну владу законною, 
а чинні правові норми такими, що не порушують прав i свобод, а навпаки - захищають. Якщо влада перевищує свої повноваження та порушує фундаментальні права людини, можливо провести перевибори.

Говорячи про демократію, варто зазначити, що в іiі основі визнання суверенності та верховенства влади народу, який відстоює свої права, інтереси й свободи через відповідних представників у владі. Демократичні цінності потребували розвитку парламентаризму, створення інституту відкритих загальних таємних виборів. Щоб демократія не трансформувалася в диктатуру більшості, ії обмежили внаслідок поділу влади на законодавчу, виконавчу та судову. Цей принцип передбачав, що жодна з гілок влади не може виконувати повноваження іншої, а це обумовило створення механізмів незалежності кожної гілки влади, розподілу повноважень між ними, прозорої й незалежної судової системи. Свідомий підхід до вибору влади - це критично та раціонально ставитися до політичних лідерів, партій, інститутів, їхніх програм. Саме демократія уповноважує громадян на переобрання влади та контроль неї з боку громадськості.

Варто акцентувати увагу, що для всіх «молодих» демократій найбільша цінність - це суспільство, яке розвинуте, активне та дієве. Саме коли люди об'єднуються з метою захистити та вибороти свої права, інтереси й свободи, вони продукують умови для переходу суспільства на якісно новий рівень. У європейському просторі ці люди також стають громадянами, адже громадянство - не лише належність до певної держави, а й активна участь у громадському та політичному житті. Громадянське суспільство $є$ своєрідним фундаментом у функціонуванні всіх типів демократії [17]. Водночас воно потребує створення вільних, незалежних від держави асоціацій громадян і неурядових організацій, які захищають інтереси своїх членів і беруть участь у політичному житті, обговоренні та розв'язанні суспільних проблем.

3 огляду на вказане вище зазначимо, що громадянське суспільство може розвиватися лише в умовах демократії. Своєю чергою, демократія процвітає у правовій державі, в якій існує верховенство права, а закон ефективно охороняє та захищає права і свободи людини та громадянина. Отже, високорозвинуте та реально функціонуюче громадянське суспільство може бути надбанням держави, яка одночасно і правова, і демократична.

Прогресивний розвиток держави можливий за умов, коли вона взаємодіє з громадянським суспільством завдяки як діалогу, так і прямій участі громадськості в публічному управлінні. Важливо, щоб ця взаємодія відбувалася на засадах рівного партнерства, взаємної відповідальності, контролю та обмеження, адже лише в такому разі механізм забезпечення прав і свобод людини та громадянина буде дієвий та ефективний, що, зі свого боку, мінімізує можливість узурпації влади.

До речі, лише налагодження дієвих механізмів контролю діяльності влади спроможне забезпечити оцінку дій влади i, в разі невідповідності суспільним інтересам, - iї коригування. 
Водночас дієвий контроль над владою можливий лише в межах демократичної конституційної держави, де влада розосереджена, врегульована, обмежена правом, доступна, передбачувана, ефективна. Демократія як принцип внутрішньої організації й діяльності політичних інститутів явище високорозвинутого громадянського суспільства [17, с. 28].

Проаналізувавши все викладене вище, вважаємо, що ідея громадського контролю розкривається як обмежувальна функція суспільства (подібно до обмежувальної функції права), що дозволяє забезпечити зворотний зв'язок з метою діяльності влади у відповідності та в порядку, визначеному законом.

У правовій доктрині, окрім громадського контролю, часто зустрічаються категорії, як-от: «суспільний контроль», «соціальний контроль», «громадянський контроль», «цивільний контроль» та «публічний контроль». Тому для кращого розуміння сутності громадського контролю (окрім окреслення його ціннісно-нормативних засад та ідеї) необхідно відокремити його від схожих за властивостями феноменів.

Так, ототожнення громадського контролю із суспільним грунтується на тому, що нині набуває актуальності концепція громадянського розвитку спільноти. Однак, зіставляючи ці два поняття, необхідно виходити 3 того, що в ідеалі громадянське суспільство - «це суспільство, в якому держава та суспільство утворюють дві чітко поділених між собою сфери, причому держава має виключно інструментальний характер, контролюючи індивідуальні інтереси в разі виникнення потреби, з урахуванням того, що вона сама знаходиться під контролем» [18, с. 41]. 3 огляду на зазначене, оскільки взаємодія між державою і суспільством не обмежується винятково контролем, доцільніше для цієї форми застосовувати поняття «громадський контроль». До того ж, термінологічно поняття «громадський» більше походить від поняття «громада».

Щодо ототожнення громадського контролю 3 соціальним, то 3 огляду на те, що громадський контроль визначається одним із видів соціального контролю, який здійснюється об'єднаннями громадян та безпосередньо громадянами, а також $є$ важливою формою реалізації конституційних прав громадян та активним способом залучення населення до управління державою [19], його самостійність є очевидною. Своєю чергою, зазначимо, що громадський контроль і соціальний співвідносяться як ціле і частина.

Проводячи межу між громадським і громадянським видами контролю, на особливу увагу заслуговує думка В. Кравчука, який вважає за доцільне розрізняти громадський і громадянський контроль, підкреслюючи, що ключовою ознакою розмежування понять «громадський контроль» і «громадянський контроль» $є$ колективність та індивідуальність суб'єктів їх здійснення. Саме тому «громадський контроль» реалізується у формах громадських рад, громадських експертиз, громадських слухань тощо, а «громадянський контроль» виявляється у формах індивідуальних звернень громадян, їхньої особистої активності» [20, с. 89]. 
Щодо цุивільного контролю, то сьогодні цей термін також досить умовно відмежований від громадського контролю. Аналіз наукової та навчальної літератури, дозволяє стверджувати, що цивільний контроль наділений практично всіма визначальними ознаками громадського контролю. Варто зауважити, що це поняття має свою специфіку. Це пов’язано 3 тим, що з англійської мови воно дослівно перекладається як «цивільний контроль над армією». I нині саме цей термін закріпився у вітчизняній воєнно-науковій літературі. 3 огляду на це, «цивільний контроль» апріорі має особливий об'єкт контролю - військовий блок держави.

Наголосимо, що термін «цивільний контроль» знайшов законодавче вираження. Спочатку в Законі України «Про демократичний цивільний контроль над Воєнною організацією і правоохоронними органами держави», а згодом у Законі України «Про національну безпеку України». Аналіз вказаних нормативно-правових актів дозволяє стверджувати, що законодавець розглядає громадський і цивільний види контролю як такі, що перетинаються (взаємно накладаються). Так, у військовій сфері є елемент громадського контролю (який є елементом цивільного контролю). Своєю чергою, цивільний контроль є одним із напрямів громадського контролю (цивільний контроль - елемент громадського контролю). Тобто, розмежування зазначених видів контролю залежить від того, що є первинним об'єктом дослідження.

Розкриваючи взаємозв'язок громадського та публічного видів контролю, варто зазначити, що концепція публічного контролю міцно утвердилася в західноєвропейській правовій доктрині (для вітчизняної юриспруденції вона є відносно новою). Тож не дивно, що переважна більшість наявних визначень цього поняття належать закордонним вченим.

Також поняття «публічний контроль» не залишили поза увагою як російські, так і українські вчені. Деякі вітчизняні науковці (допускаємо, що таких більшість) обмежуються згадуванням цього поняття в тексті дослідження через співвідношення його із суміжними поняттями [3]. Інші, хоча й присвячують цьому питанню окреме дослідження, однак жодним чином не специфікують його. Зі свого боку, російські дослідники розглядають це поняття як окреме правове явище. Аналіз найбільш обгрунтованих наукових тверджень (М. Баранова та А. Буханевича) виявив, що вади запропонованих вченими визначень є численними та очевидними, що не дозволяє говорити про їхню загальновизнаність. Є спільні: нечіткість, неконкретність тощо. А $€$ й окремі. Зокрема, М. Баранов зводить поняття «контроль» виключно до поняття «налагодження», що не відповідає змісту контролю. Крім того, науковець, говорячи про законодавчі та виконавчі рішення, залишає поза увагою їх реалізацію. А. Буханевич також досить вузько трактує контроль, розглядаючи його як нагляд, що є окремим правовим явищем. До того ж, у частині правових норм він змішує поняття «санкціонування» та «установлення», які регулюють відносини у сфері функціонування громадського контролю. 
Нині складно чітко розмежувати публічний та громадський види контролю, адже ідеї, які лежать в їхній основі, частково накладаються. Спільними ознаками цих видів контролю $є$ те, що вони $є$ ключовими факторами демократичних процесів, безпосередньо пов'язаними із формуванням громадянського суспільства та є механізмами впливу на владу.

Відмінності зведено у таблииі.

Таблиия

Відмінності громадського і публічного контролю

\begin{tabular}{|c|c|c|}
\hline \multirow{2}{*}{ Критерій } & \multicolumn{2}{|c|}{ Вид контролю } \\
\hline & Громадський & Публічний \\
\hline Сфера застосування & Державна політика & Публічна політика \\
\hline \begin{tabular}{|l|} 
Вплив на грома- \\
дянське суспільство
\end{tabular} & С умовою становлення & Є умовою розвитку \\
\hline $\begin{array}{l}\text { Вектор впливу } \\
\text { контрольного } \\
\text { механізму на владу }\end{array}$ & На державну владу & $\begin{array}{l}\text { На публічну владу (включає } \\
\text { також місцеве самоврядування } \\
\text { та недержавні суб’єкти деле- } \\
\text { гованих повноважень під час } \\
\text { здійснення виконавчих функцій) }\end{array}$ \\
\hline Юридична сутність & $\begin{array}{l}\text { Являє собою незаборонені фор- } \\
\text { ми діяльності громадськості, } \\
\text { з метою забезпечення функ- } \\
\text { ціонування державної влади } \\
\text { відповідно до норм Конститу- } \\
\text { ції України, законів України, } \\
\text { інших нормативно-правових } \\
\text { актів та дотримання її органами, } \\
\text { посадовими та службовими } \\
\text { особами державної дисципліни }\end{array}$ & $\begin{array}{l}\text { Є діяльністю суспільства } \\
\text { з метою забезпечення функ- } \\
\text { ціонування публічної влади } \\
\text { відповідно до поставленої } \\
\text { мети, суспільних цілей. } \\
\text { Тому громадський контроль } \\
\text { є частиною публічного } \\
\text { контролю }\end{array}$ \\
\hline
\end{tabular}

Джерело: узагальнено $і$ зведено авторами.

Як видно $з$ таблиці, громадський контроль $є$ частиною публічного контролю.

Для комплексного розгляду проблеми цього дослідження доцільно розглянути ще одне важливе питання, з яким прямо пов'язане визначення правової природи громадського контролю. Йдеться про походження права на здійснення громадського контролю, щодо якого нині існують доволі неоднозначні наукові твердження. Зокрема, більшість вітчизняних вчених пов'язує громадський контроль із правом на участь в управлінні державними справами. Водночас дослідники не розглядають питання співвідношення цих понять, їхніх спільних та відмінних ознак, що не дозволяє впевнено говорити про взаємообумовленість правових природ цих правових явищ.

Для виявлення ступеня самостійності права на здійснення громадського контролю важливо дослідити основні підходи до визначення права на участь в управлінні державними справами. 
Так, право на участь в управлінні державними справами є об’єктом досліджень як вітчизняних, так і закордонних науковців. Передусім на особливу увагу заслуговують праці американських вчених, адже сьогодні саме США $є$ найяскравішим прикладом зрілої демократії. Так, науковці К. Джанда, Дж. Бері та Дж. Голдман визначають участь в управлінні державними справами як політичну участь, що проявляється діями окремих громадян, які певним чином намагаються вплинути на державну владу та державну політику [21, с. 226].

Наукові доробки російських вчених щодо участі в управлінні державними справами не є цінними. Це обумовлено тим, що в процесі вітчизняного державотворення вплив радянської правової системи на вітчизняну правову науку істотно знизився, в результаті чого сучасна українська наука розвивається у зовсім іншому напрямі, зокрема, актуалізуючи забезпечення політичних прав громадян як першочергову необхідність. Адже в такому форматі взаємовідносин «громадянин держава» найяскравіше проявляється їхня демократична природа.

Право на участь в управлінні державними справами також вивчалось і українськими науковцями. Зокрема, А. Грабильніков розглядає це право як передбачену законодавством можливість громадянина брати участь у здійсненні безпосереднього народовладдя через участь у виборах i peферендумах, рівний доступ до державної служби й служби в органах місцевого самоврядування, участь у здійсненні правосуддя [22, с. 3-4].

А. Драшкович тлумачить політичну участь громадян у більш широкому розумінні, визначаючи її як безперервну взаємодію влади та громадян, яка стосується всього циклу прийняття та реалізації рішення й визначає ефективні методи залучення громадян до участі у прийнятті владного рішення, до яких відносить: інформування, консультації, громадський контроль (у різних формах) тощо [23].

3 позицій демократичного розвитку України на особливу увагу заслуговує думка О. Скібіної, яка визначає участь громадян в управлінні державними справами як діяльність громадян у сфері здійснення державної влади, яка є свідомою, вільною, активною, публічною, добровільною, цілеспрямованою, законною, а також здійснюється, щоб формувати та контролювати діяльність державних органів, впливати на прийняття, здійснення та реалізацію державних рішень [24, с. 3].

Подібну позицію поділяє й О. Чуб, яка розглядає участь в управлінні державними справами як конституційне право громадян, яке передбачає можливість їхньої активної, публічної, добровільної, цілеспрямованої, законної діяльності у сфері здійснення державної влади, метою якої є формування державних органів, контроль за їхньою діяльністю, вплив на прийняття, виконання державних рішень та контроль за їхньою реалізацією [25, с. 7].

Отже, історично та концептуально право на участь в управлінні державними справами є основним (конституційним) правом. Сьогодні з огляду на зміцнення позицій концепту демократичної правової держави, 
громадянського суспільства це право набуває більш комплексного характеру, тлумачиться ширше, передбачає певні форми реалізації та, відповідно, потребує перегляду як у суто теоретичних, так і практичних цілях. Громадський контроль - це фундаментальна форма реалізації цього права, яка дозволяє забезпечити взаємодію держави та громадянського суспільства на засадах рівного партнерства, взаємної відповідальності, взаємоконтролю та взаємообмеження.

Висновки. Правова природа громадського контролю являє собою ціннісно-нормативні засади взаємодії держави та суспільства, які обумовлюють виникнення і розвиток ідеї обмеження діяльності держави з метою задоволення суспільних інтересів, що забезпечується, зокрема, внаслідок функціонування зворотного зв'язку між державною владою та суспільством. Сьогодні громадський контроль варто розуміти як одну із форм прояву права на участь в державному управлінні, що забезпечує організацію та здійснення державної влади у напрямі реалізації завдань, функцій і повноважень, покладених на неї законом, а також досягнення основної мети - забезпечення прав і свобод людини та гідних умов їі життя.

\section{СПИСОК ВИКОРИСТАНИХ ДЖЕРЕЛ}

1. Vasylchenko O., Lotiuk O., Kudriavtseva O., Kravtsova Z. Public control over the actions of government in the field of research and rational use of mineral resources. Naukovyi Visnyk Natsionalnoho Hirnychoho Universytetu. 2019. № 4. P. 102-106.

2. Наливайко Л. Р., Савченко О.В. Теоретико-правові засади громадського контролю за діяльністю органів державної влади: монографія. Київ: Хай-Тек Прес, 2017. 275 c.

3. Поклад О. В. Громадський контроль за діяльністю поліції: дис. ... канд. юрид. наук: 12.00.07. Запоріжжя, 2018. $207 \mathrm{c.}$

4. Смоляр О.А. Державний та громадський контроль у сфері місцевого самоврядування: автореф. дис. ... канд. юрид. наук: 12.00.02. Харків, 2017. 20 с.

5. Ткаченко Р. О. Громадський контроль за діяльністю органів Національної поліції України: автореф. дис. ... канд. юрид. наук: 12.00.07. Кривий Ріг, 2019. 20 с.

6. Хотинська-Нор О. З. Форми та способи громадського контролю в судовій системі України. Visegrad journal on human rights. 2016. № 2/1. С. 135-140. URL: http://vjhr.sk/archive/2016_2_1/22.pdf.

7. Комиссарова Е. Г. Формально-логические аспекты понятия «правовая природа». Вестник Пермского университета. 2012. № 2 (16). С. 23-27.

8. Алексеев С. С. Общие дозволения и запреты в советском праве. М.: Юрид. лит., 1998. 288 с.

9. Матвеев И. В. Правовая природа недействительных сделок: дис. ... канд. юрид. наук: 12.00.03. М., 2002. 192 с.

10. Словник української мови: в 11 т.; за ред. І. К. Білодіда. Київ: Наукова думка, 1977. T. $8.456 \mathrm{c}$.

11. Найповніший тлумачний словник української мови онлайн. URL: https://eslovnyk.com.

12. Кисельов М. Природа: філософський енциклопедичний словник. Київ: Абрис, 2002. $742 \mathrm{c}$

13. Скороходько Е. Ф. Термін у науковому тексті. Київ: Логос, 2006. 99 с. 
14. Павленко С. А. Правова природа інституту адміністративних послуг. Правове регулювання суспільних відносин в умовах євроінтеграції: тези доп. інтернетконференції (Черкаси, 17-18 березня 2015 року). Черкаси: Черкаський національний університет ім. Б. Хмельницького, 2015. С. 75-81.

15. Максимов С. И. Правовая реальность: опыт философского осмысления. Харьков: Право, 2002. 328 с.

16. Соломін О. А. Концепція правової держави: сучасний контекст. Наукові записки НаУKMA. 2012. T. 134. C. 3-6. URL: http://nbuv.gov.ua/UJRN/NaUKMAp_2012_134_3.

17. Ковлер А. И. Кризис демократии? Демократия на рубеже XX $\mathrm{X}$ века. М.: Институт государства и права РАН, 1997. 103 с.

18. Вітвіцький С. С. Інститут громадянського контролю в Україні: поняття, сутність, тенденції розвитку. Науковий вісник Дніпропетровського держсавного університету внутрішніх справ. 2013. № 1. с. 40-47.

19. Проблеми реалізації Конституції України: теорія і практика: монографія; за ред. В. Ф. Погорілко. Київ: А. С. К., 2001. 356 с.

20. Кравчук В. М. Контроль над публічною владою: уточнення понятійно-категорійного апарату. Visegrad Journal on Human Rights. 2016. № 1. С. 85-90.

21. Janda K., Berry J. et al. The challenge of democracy: government in America. Boston: Houghton Mifflin Company, 1989. 822 p.

22. Грабильніков А. В. Конституційне право громадян України брати участь в управлінні державними справами: проблеми теорії і практики: дис. ... канд. юрид. наук: 12.00.02. Київ, 2006. 187 с.

23. Драшкович А. Політична участь громадян в процесі прийняття владних рішень. Політологічні записки. 2013. № 7. URL: http://nbuv.gov.ua/j-pdf/Polzap_2013 7 28.pdf.

24. Скібіна О. О. Поняття участі громадян в управлінні державними справами: конституційно-правовий аспект. Вісник Харків. наи. ун-ту внутр. справ. 2003. № 22. URL: http://nbuv.gov.ua/j-pdf/VKhnuvs_2003_22_62.pdf.

25. Чуб О. О. Конституційне право громадян України на участь в управлінні державними справами: дис. ... канд. юрид. наук: 12.00.02. Харків, 2004. 212 с.

Стаття надійшла до редакиії 22.10.2019.

\section{Gurzhiy T., Kovalenko Zh. Public control as a legal form of interaction between the state and society. \\ Background. The speed and efficiency of reforming all major spheres of social} life, the adaptation of national legislation to European Union law depend on many factors, among which the legitimacy of public authority, which can be secured, in particular, through the establishment of public relations, is crucial. One form of such communication is public control, which is not only a necessary element of civil society, but also a clear manifestation of the constitutional thesis that power in the country comes from the people.

Materials and methods. The methodological basis of the research is general scientific and special methods, in particular: dialectical, structural-logical, systemic, logical-semantic, methods of classification and grouping, comparative-legal method and method of scientific abstraction. These methods were applied in conjunction with common logical methods and techniques.

Results. The basic approaches to the definition of the term «legal nature» are analyzed and the criteria for its definition are clarified. A distinction is made between public control and related concepts. The relation between the concepts of "public control» and "participation in the management of public affairs» is revealed.

Conclusion. The author's vision of the concept of "legal nature of public control" is grounded, which not only brings clarity on the level of legal science, but also allows to 
determine the way of legal regulation of relevant social relations. It seems that this will improve the mechanisms of interaction between the state and society.

Keywords: legal nature, state, society, public control, participation in the management of public affairs.

\section{REFERENCES}

1. Vasylchenko, O., Lotiuk, O., Kudriavtseva, O., \& Kravtsova, Z. (2019). Public control over the actions of government in the field of research and rational use of mineral resources. Naukovyi Visnyk Natsionalnoho Hirnychoho Universytetu Scientific bulletin of the National Mining University, 4, 102-106 [in English].

2. Nalyvajko, L. R., \& Savchenko, O. V. (2017). Teoretyko-pravovi zasady gromads'kogo kontrolju za dijal'nistju organiv derzhavnoi' vlady [Theoretical and legal principles of public control over the activity of public authorities]. Kyi'v: Haj-Tek Pres [in Ukrainian].

3. Poklad, O. V. (2018). Gromads'kyj kontrol' za dijal'nistju policii' [Public control over police activities]. Candidate's thesis. Zaporizhzhja [in Ukrainian].

4. Smoljar, O. A. (2017). Derzhavnyj ta gromads'kyj kontrol' u sferi miscevogo samovrjaduvannja [State and public control in the field of local self-government]. Extended abstract of candidate's thesis. Harkiv [in Ukrainian].

5. Tkachenko, R. O. (2019). Gromads'kyj kontrol' za dijal'nistju organiv Nacional'noi' policii' Ukrai'ny [Public control over the activities of the National police of Ukraine]. Extended abstract of candidate's thesis. Kryvyj Rig [in Ukrainian].

6. Hotyns'ka-Nor, O. Z. (2016). Formy ta sposoby gromads'kogo kontrolju v sudovij systemi Ukrai'ny [Forms and methods of public control in the judicial system of Ukraine]. Visegrad journal on human rights, 2/1, 135-140. Retrieved from http://vjhr.sk/ archive/2016_2_1/22.pdf [in Ukrainian].

7. Komissarova, E. G. (2012). Formal'no-logicheskie aspekty ponjatija "pravovaja priroda" [Formal and logical aspects of the concept of "legal nature"]. Vestnik Permskogo universiteta - Bulletin of Perm University, 2 (16), 23-27 [in Russian].

8. Alekseev, S. S. (1998). Obshhie dozvolenija i zaprety v sovetskom prave [General permissions and prohibitions in soviet law]. Moscow: Juridicheskaja literatura [in Russian].

9. Matveev, I. V. (2002). Pravovaja priroda nedejstvitel'nyh sdelok [Legal nature of invalid transactions]. Candidate's thesis. Moscow [in Russian].

10. Slovnyk ukrai'ns'koi' movy. [Dictionary of the Ukrainian language]. (1977). I. K. Bilodid (Ed.). (Vol. 8). Kyi'v: Naukova dumka [in Ukrainian].

11. Najpovnishyj tlumachnyj slovnyk ukrai'ns'koi' movy onlajn [The most complete Ukrainian-language online dictionary]. Retrieved from https://eslovnyk.com [in Ukrainian].

12. Kisel'ov, M. (2002). Priroda: filosofs'kij enciklopedichnij slovnik [Nature: a philosophical encyclopedic dictionary]. Kiïv: Abris [in Ukrainian].

13. Skorohod'ko, E. F. (2006). Termin u naukovomu teksti [A term in a scientific text]. Kiïv: Logos [in Ukrainian].

14. Pavlenko, S. A. (2015). Pravova priroda institutu administrativnih poslug [The legal nature of the institute of administrative services]. Pravove reguljuvannja suspil'nyh vidnosyn $v$ umovah jevrointegracii' - Legal regulation of social relations in the context of European integration. Tezy dopovidej internet-konferencii' - Abstracts of Internet conference reports, (17-18. 03), (pp. 75-81). Cherkasy: Cherkas'kyj nacional'nyj universytet im. B. Hmel'nyc'kogo [in Ukrainian].

15. Maksimov, S. I. (2002). Pravovaja real'nost': opyt filosofskogo osmyslenija [Legal reality: the experience of philosophical understanding]. Har'kov: Pravo [in Russian]. 
16. Solomin, O. A. (2012). Koncepcija pravovoi' derzhavy: suchasnyj kontekst [The concept of the legal state: the modern context]. Naukovi zapysky NaUKMA - NaUKMA scientific notes. (Vol. 134), (pp. 3-6). Retrieved from http://nbuv.gov.ua/UJRN/ NaUKMAp_2012_134_3 [in Ukrainian].

17. Kovler, A. I. (1997). Krizis demokratii? Demokratija na rubezhe XXI veka [The crisis of democracy? Democracy at the turn of the 21st century]. Moscow: Institut gosudarstva i prava RAN [in Russian].

18. Vitvic'kyj, S. S. (2013). Instytut gromadjans'kogo kontrolju v Ukrai'ni: ponjattja, sutnist', tendencii' rozvytku [Institute for civil control in Ukraine: concept, essence, development trends]. Naukovyj visnyk Dnipropetrovs'kogo derzhavnogo universytetu vnutrishnih sprav - Scientific bulletin of Dnipropetrovsk State University of Internal Affairs, 1, 40-47 [in Ukrainian].

19. Problemy realizacii' Konstytucii' Ukrai'ny: teorija i praktyka [Problems of implementation of the Constitution of Ukraine: theory and practice]. (2001). V. F. Pogorilko (Ed.). Kyi'v: A. S. K. [in Ukrainian].

20. Kravchuk, V. M. (2016). Kontrol' nad publichnoju vladoju: utochnennja ponjatijnokategorijnogo aparatu [Control over public authority: clarification of the conceptualcategorical apparatus]. Visegrad Journal on Human Right, 1, 85-90 [in Ukrainian].

21. Janda, K., Berry J. M. et al. (1989). The challenge of democracy: government in America. Boston: Houghton Mifflin Company [in English].

22. Grabyl'nikov, A. V. (2006). Konstytucijne pravo gromadjan Ukrai'ny braty uchast' v upravlinni derzhavnymy spravamy: problemy teorii' i praktyky [The Constitutional right of Ukrainian citizens to participate in public affairs management: problems of theory and practice]. Candidate's thesis. Kyi'v [in Ukrainian].

23. Drashkovych, A. (2013). Politychna uchast' gromadjan v procesi pryjnjattja vladnyh rishen' [Political participation of citizens in the power decision-making process]. Politologichni zapysky - Political Science Notes, 7. Retrieved from http://nbuv.gov.ua/ jpdf/Polzap_2013_7_28.pdf [in Ukrainian].

24. Skibina, O. O. (2003). Ponjattja uchasti gromadjan v upravlinni derzhavnymy spravamy: konstytucijno-pravovyj aspekt [The concept of citizen participation in public affairs management: constitutional and legal aspects]. Visnyk Harkivs'kogo nacional'nogo universytetu vnutrishnih sprav - Bulletin of the Kharkiv National University of Internal Affairs, 22. Retrieved from http://nbuv.gov.ua/j-pdf/VKhnuvs_2003_22_62.pdf [in Ukrainian].

25. Chub, O. O. (2004). Konstytucijne pravo gromadjan Ukrai'ny na uchast' v upravlinni derzhavnymy spravamy [Constitutional right of citizens of Ukraine to participate in the management of state affairs]. Candidate's thesis. Harkiv [in Ukrainian]. 